\title{
Situation of Water, Sanitation and Hygiene and Diarrhoeal Diseases After Open Defecation Free Declaration
}

\author{
Simrin Kafle, ${ }^{1}$ Bandana Pradhan ${ }^{2}$ \\ ${ }^{1}$ Maharajgunj Medical Campus, Institute of Medicine, Tribhuvan University, Kathmandu, Nepal. ${ }^{2}$ Department \\ of Community Medicine and Public Health, Institute of Medicine, Kathmandu, Nepal.
}

\begin{abstract}
Background: Makwanpur district was declared Open Defecation Free in 2013 as the movement started in Nepal since 2003 to address the high burden of diarrhoeal disease among under five children. As the water supply, sanitation and hygiene situation of the district is not known after the declaration, the need for this study was visualized.

Methods: It was a cross sectional study among randomly sampled 178 households using interview and observation. Water, sanitation and hygiene situation was assessed in terms of related facilities, knowledge and practices of mothers. Results were compared with the standard open defecation free criteria of Nepal. Five years trend of diarrhoeal disease was analysed from the health facility records to assess the impact of declaration.

Results: Of the total households 92\% had toilets and 90\% had access to improved water source. About 79\% mothers had high knowledge on safe water, sanitation and hygiene and $43 \%$ practiced hand washing with soap at critical times. Proper disposal of solid and liquid waste was found among $32 \%$ and $46 \%$ of households respectively. About $68 \%$ of households had good water, sanitation and hygiene situation and was found to be significantly associated with related knowledge among mothers irrespective of their economic status. Diarrhoeal disease among under five children was found declining after open defecation free declaration.

Conclusions: Water, sanitation and hygiene status in the study area is found lower than the criteria for open defecation free declaration. However, diarrhoeal disease among children under five is declining after the declaration.

Keywords: Diarrhoeal disease; Makwanpur; ODF;WASH
\end{abstract}

\section{INTRODUCTION}

Despite a significant progress in reducing child mortality and morbidity from 1996 to 2016, burden of water, sanitation and hygiene (WASH) associated diseases remains high in Nepal. ${ }^{1}$ The diarrheal disease is the second largest killer among under five children in Nepal. ${ }^{2}$ As efforts to address the diarrhoeal disease through improved sanitation situation, Community Led Total Sanitation, a part of ODF movement started in Nepal since 2003. ${ }^{3}$ By the end of August 2017, about 27 districts have been declared ODF. ${ }^{4}$ Makwanpur district was declared in $2013 .{ }^{5}$ As a component of the programme for preparation to the next phase of total sanitation, follow up assessment was not conducted in Makwanpur district after declaring ODF. Therefore, this study was conceived with objective to assess the post ODF situation of sanitation facilities and hygiene practice in Makwanpur district.

\section{METHODS}

Study was conducted in Churiyamai VDC (now Churiyamai consists of 16, 17 and 18 wards of Hetauda Municipality) Makwanpur with 14,274 population. ${ }^{6}$ A cross sectional study was conducted through face to face interview using pretested questionnaire and observation checklist from Nepal Demographic Health Survey 2011 and Nepal Sanitation and Hygiene Master Plan 2011. These tools were used to assess the WASH situation of households. WASH situation of households was assessed in three areas namely WASH related knowledge among mothers, WASH related facilities and WASH related practices among mothers. For the calculation of wealth quintile of households, principal component analysis (PCA) was done. About 14 variables were included namely the possession of television, cupboard, fan, mobile, LPG gas, bicycle, motorcycle, ownership of land, amount of land possessed, possession of any livestock, access to toilet facility, electricity, piped water supply and house type
DOI: http://dx.doi.org/10.3126/ inhrc.v16i2.20303
Correspondence: Ms Simrin Kafle, Maharaiguni Medical Campus, Institute of Medicine, Tribhuvan University, Kathmandu, Nepal. Email: simrinkafle@gmail.com, Phone: +9779849643266 . 
for calculating wealth index which placed the individual households on a continuous scale of relative wealth. The relative continuous scales of household wealth index were again classified into three classes such as lowest, medium and highest wealth quintile for the study.

Study population was mothers having children below five years age selected using systematic random sampling. Sampling frame was obtained from health facility records of Vitamin A distribution. Sample size was derived by using the formula for known population ${ }^{7}, \mathrm{n}=\mathrm{NZ}^{2} \mathrm{PQ} /$ $\mathrm{e}^{2}(\mathrm{~N}-1)+\mathrm{Z}^{2} \mathrm{PQ}$ (where, $\mathrm{n}=$ required sample size, $\mathrm{N}=$ total eligible mothers, $\mathrm{z}=$ percentiles of the standard normal distribution corresponding to $95 \%$ confidence level which is equals to $1.96, \mathrm{P}=$ Percent of households having toilet is $85 \%$. With the addition of four percent non response rate $^{1}$, the total sample was 178 households. Data was analyzed using SPSS version 21.

\section{RESULTS}

Table 1 shows majority of the study participants (81\%) were Tamang. Half of them lived in nuclear family. About 74\% followed Buddhism as their religion. Majority of mothers (83\%) were doing household chores as their main occupation. Out of total mothers, $99 \%$ were able to read and write.

\begin{tabular}{|c|c|c|c|}
\hline Characteristics & n (\%) & Characteristics & n (\%) \\
\hline Caste/ethnicity & & $\begin{array}{l}\text { Major } \\
\text { occupation }\end{array}$ & \\
\hline Tamang & $\begin{array}{l}146 \\
(82.0)\end{array}$ & $\begin{array}{l}\text { Household } \\
\text { work }\end{array}$ & $\begin{array}{l}147 \\
(82.6)\end{array}$ \\
\hline Others & $\begin{array}{l}32 \\
(18.0)\end{array}$ & Business & $\begin{array}{l}13 \\
(7.3)\end{array}$ \\
\hline Type of family & & Agriculture & $\begin{array}{l}5 \\
(2.8)\end{array}$ \\
\hline Nuclear & $\begin{array}{l}90 \\
(50.6)\end{array}$ & Daily wages & $\begin{array}{l}13 \\
(7.3)\end{array}$ \\
\hline Joint/extended & $\begin{array}{l}88 \\
(49.4)\end{array}$ & $\begin{array}{l}\text { Education } \\
\text { status }\end{array}$ & \\
\hline $\begin{array}{l}\text { Language } \\
\text { spoken }\end{array}$ & & Literate & $\begin{array}{l}176 \\
(98.8)\end{array}$ \\
\hline Tamang & $\begin{array}{l}118 \\
(66.3)\end{array}$ & Illiterate & 2 \\
\hline Nepali & $\begin{array}{l}60 \\
(33.7)\end{array}$ & & \\
\hline \multicolumn{4}{|l|}{ Religion } \\
\hline Buddhist & $\begin{array}{l}121 \\
(68.0)\end{array}$ & & \\
\hline Hindu & $\begin{array}{l}57 \\
(32.0)\end{array}$ & & \\
\hline
\end{tabular}

Table 2 indicates about $80 \%$ of the mothers had knowledge about hand washing at the critical times. Almost all mothers had knowledge about at least one method of water purification. Knowledge of mothers about proper methods of solid and liquid waste management was found to be $66 \%$ and $77 \%$ respectively. Majority of mothers $(79.2 \%)$ were found to have high knowledge about WASH with 6-9 scores.

\section{Table 2. Knowledge of mothers about WASH ( $n=178)$.}

\begin{tabular}{|c|c|c|c|}
\hline S.N & Knowledge on & Number & Percent \\
\hline 1 & $\begin{array}{l}\text { At least one method } \\
\text { of water purification } \\
\text { (boiling, chlorination, } \\
\text { filtration, solar } \\
\text { water disinfection, } \\
\text { sedimentation and filter } \\
\text { with a cloth) }\end{array}$ & 176 & 98.9 \\
\hline 2 & $\begin{array}{l}\text { Hand washing with soap } \\
\text { before eating }\end{array}$ & 142 & 79.8 \\
\hline 3 & $\begin{array}{l}\text { Hand washing with soap } \\
\text { before feeding child }\end{array}$ & 113 & 63.5 \\
\hline 4 & $\begin{array}{l}\text { Hand washing with soap } \\
\text { before preparing food }\end{array}$ & 85 & 47.8 \\
\hline 5 & $\begin{array}{l}\text { Hand washing with soap } \\
\text { after defecation }\end{array}$ & 175 & 98.3 \\
\hline 6 & $\begin{array}{l}\text { Hand washing with soap } \\
\text { after cleaning child's } \\
\text { stool }\end{array}$ & 173 & 97.2 \\
\hline \multirow[t]{2}{*}{7} & $\begin{array}{l}\text { Hand washing with soap } \\
\text { after working in the } \\
\text { field }\end{array}$ & 164 & 92.1 \\
\hline & $\begin{array}{l}\text { Hand washing with soap } \\
\text { at critical times }\end{array}$ & 852 & 79.7 \\
\hline 8 & $\begin{array}{l}\text { Proper disposal of solid } \\
\text { waste (garbage and } \\
\text { refuse) }\end{array}$ & 118 & 66.3 \\
\hline \multirow[t]{5}{*}{9} & $\begin{array}{l}\text { Proper disposal of liquid } \\
\text { waste }\end{array}$ & 137 & 77.0 \\
\hline & \multicolumn{3}{|c|}{ Knowledge level of mothers about WASH } \\
\hline & Low (0-5 score) & 37 & 20.8 \\
\hline & High (6-9 score) & 141 & 79.2 \\
\hline & Total & 178 & 100.0 \\
\hline
\end{tabular}

Table 3 demonstrates of the total, $92 \%$ households had toilets and $90 \%$ of the households had access to improved water source. About $93 \%$ of the households used toilets indicating that few households use toilets of neighbors in regular basis. Less than half of the mothers (43\%) practiced hand washing with soap at critical times with the poorest practice of hand washing before preparing food. Waste management was found relatively poor among households. About $53 \%$ of households had animal shed inside or attached to the house. Proper disposal of solid and liquid waste was found only among $32 \%$ and $46 \%$ of households, respectively. 
Table 3 also depicts 12 indicators of WASH status; two of them demonstrate WASH related facilities and 10 of them shows WASH related practices. All of these indicators were included in the assessment of WASH status with the score of 1 or 0 in each. WASH situation of households was then categorized into poor with 0-6 score and good WASH situation who obtained 7-12 score. More than two third $(68 \%)$ of households had good WASH status.

\begin{tabular}{|c|c|c|c|}
\hline \multirow[t]{2}{*}{ S.N } & Indicators & Number & Percent \\
\hline & \multicolumn{3}{|l|}{ WASH related facilities } \\
\hline 1 & $\begin{array}{l}\text { Access to improved } \\
\text { water sources }\end{array}$ & 161 & 90.4 \\
\hline \multirow[t]{2}{*}{2} & $\begin{array}{l}\text { Availability of toilet } \\
\text { facility in the family }\end{array}$ & 164 & 92.1 \\
\hline & \multicolumn{3}{|l|}{ WASH related practices } \\
\hline 3 & $\begin{array}{l}\text { Hand washing before } \\
\text { eating }\end{array}$ & 92 & 51.7 \\
\hline 4 & $\begin{array}{l}\text { Hand washing before } \\
\text { feeding child }\end{array}$ & 86 & 48.3 \\
\hline 5 & $\begin{array}{l}\text { Hand washing before } \\
\text { preparing food }\end{array}$ & 54 & 30.3 \\
\hline 6 & $\begin{array}{l}\text { Hand washing after } \\
\text { defecation }\end{array}$ & 161 & 90.4 \\
\hline 7 & $\begin{array}{l}\text { Hand washing after } \\
\text { cleaning child's stool }\end{array}$ & 171 & 96.1 \\
\hline \multirow[t]{2}{*}{8} & $\begin{array}{l}\text { Hand washing after } \\
\text { working in the field }\end{array}$ & 130 & 73.0 \\
\hline & $\begin{array}{l}\text { Total of hand washing } \\
\text { with soap at critical } \\
\text { times }\end{array}$ & 462 & 43.2 \\
\hline 9 & Use of toilet facility & 166 & 93.3 \\
\hline 10 & $\begin{array}{l}\text { Proper disposal of child's } \\
\text { feces }\end{array}$ & 75 & 42.1 \\
\hline 11 & $\begin{array}{l}\text { Proper disposal of solid } \\
\text { waste/refusal of the } \\
\text { family }\end{array}$ & 57 & 32.0 \\
\hline \multirow[t]{5}{*}{12} & $\begin{array}{l}\text { Proper disposal of liquid } \\
\text { waste }\end{array}$ & 81 & 45.5 \\
\hline & \multicolumn{3}{|l|}{$\begin{array}{l}\text { Level of WASH status of } \\
\text { households }\end{array}$} \\
\hline & Poor $(0-6)$ & 57 & 32.0 \\
\hline & Good (7-12) & 121 & 68.0 \\
\hline & Total & 178 & 100.0 \\
\hline
\end{tabular}

Table 4 shows WASH situation of the households is significantly associated with the knowledge level of mothers. It is 12 times more likely that mothers with high knowledge on WASH have good WASH facilities and practices in their households compared to those mothers with poor knowledge $(\mathrm{OR}=12.01,95 \% \mathrm{Cl}=5.11-28.24)$.
However, no association was found between wealth quintile of households and their WASH situation.

\section{Table 4. Factors associated with WASH situation in} the households $(n=178)$.

\begin{tabular}{|c|c|c|c|c|}
\hline Factors & $\begin{array}{l}\text { WASH situ } \\
\text { the house }\end{array}$ & $\begin{array}{l}n \text { in } \\
s\end{array}$ & $\begin{array}{r}\text { OR }(95 \% \\
\mathrm{Cl})\end{array}$ & P-value \\
\hline & Poor (\%) & $\begin{array}{r}\text { Good } \\
(\%)\end{array}$ & & \\
\hline
\end{tabular}

$\begin{array}{lrrrr}\text { Low } & 28(75.7) & 9(24.3) & 1 & \\ \text { High } & 29(20.6) & 112 & 12.01 & 0.00^{*}\end{array}$

Wealth quintile of households

\begin{tabular}{lcrrrr} 
Lowest & $24(40.7)$ & 35 & 1 & \\
& & $(59.3)$ & & \\
Medium & $20(33.9)$ & $(66.1)$ & $0.40(0.1-$ & 0.02 \\
Highest & $13(21.7)$ & 47 & $0.53(0.2-$ & 0.13 \\
\hline
\end{tabular}

According to table 5 , some of the WASH related indicators in the study area were not found in place as per the criteria for ODF declaration as stipulated in Sanitation and Hygiene Master Plan, 2011. ${ }^{8}$ Only $92 \%$ of households had own toilet against cent percent in the criteria, while all the institutions had toilet facilities. Nearly $6 \%$ of the households are still using open field for defecation, and $2 \%$ share other households' toilet. Soap for hand washing was available only in $60 \%$ of the households. Similarly, the WASH related practices of environment management did not comply with the ODF declaration criteria.

\section{Table 5. Comparison of WASH situation with the} ODF criteria.

\begin{tabular}{|llll}
\hline SN & Indicators & $\begin{array}{l}\text { ODF } \\
\text { declaration } \\
\text { criteria (\%) }\end{array}$ & $\begin{array}{l}\text { WASH } \\
\text { situation } \\
(\%)\end{array}$ \\
\hline $1 \quad \begin{array}{l}\text { Open defecation in } \\
\text { the study area }\end{array}$ & 0 & 5.6 \\
\hline $2 \quad \begin{array}{l}\text { Toilet facility in } \\
\text { family }\end{array}$ & 100 & 92.1 \\
\hline $3 \quad \begin{array}{l}\text { Availability of toilets } \\
\text { in institutions }\end{array}$ & 100 & 100.0 \\
\hline $\begin{array}{l}\text { 3.1 Schools } \\
\text { 3.2 Cooperatives }\end{array}$ & 100 & 100.0 \\
\hline $\begin{array}{l}\text { 3.3 Health facility } \\
\text { 3.4 Church }\end{array}$ & 100 & 100.0 \\
\hline $\begin{array}{l}\text { 3.5 Other offices } \\
\text { Availability of soap } \\
\text { and soap case for } \\
\text { hand washing }\end{array}$ & 100 & 100.0 \\
\hline
\end{tabular}


Situation of Water, Sanitation and Hygiene and Diarrhoeal Diseases After Open Defecation Free Declaration

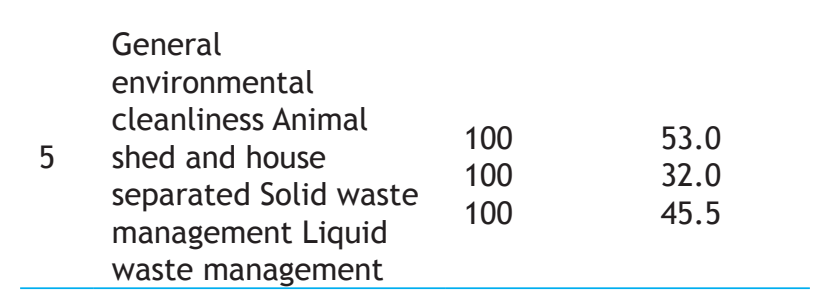

Figure 1 shows prevalence of diarrhoeal disease among children below age 5 in the last 2 months period preceding the survey was 101 per 1000. The trend analysis has indicated the occurrence of diarrhoeal disease among under five children is declining since the declaration of ODF in Churiyamai. It was 641 per 1,000 in 2011 and 346 per 1,000 in 2015 according to the health facility records.

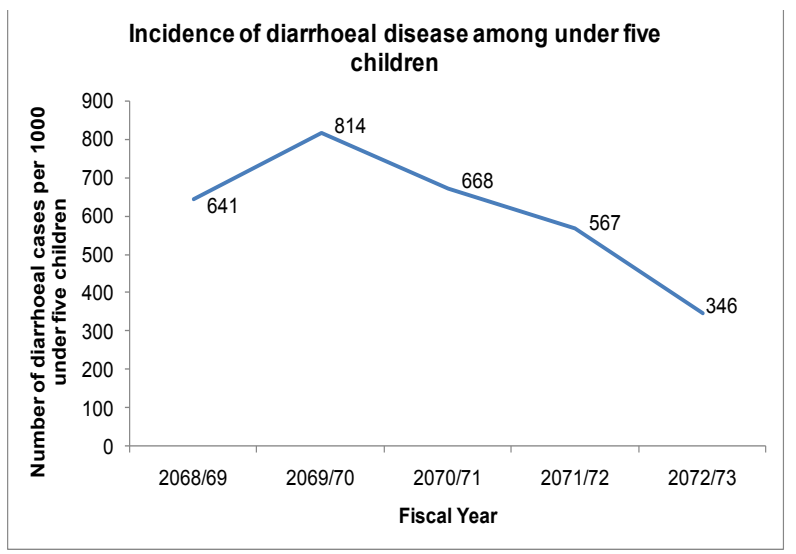

Figure 1. Trend of diarrhoeal disease among under five children in Churiyamai.

Table 6 shows significant association between WASH situation in households and diarrhoeal disease among under five years children. It was found households having good WASH situation are three times less likely to suffer their children from diarrhoeal disease compared to households with poor WASH related facilities and practices.

\begin{tabular}{|c|c|c|c|c|}
\hline Characteristics & $\begin{array}{l}\text { Occurren } \\
\text { diarrheal } \\
\text { among un } \\
\text { children }\end{array}$ & $\begin{array}{l}\text { of } \\
\text { isease } \\
\text { er } 5\end{array}$ & $\begin{array}{l}\text { OR } \\
(95 \% \\
\mathrm{Cl})\end{array}$ & P-value \\
\hline $\begin{array}{l}\text { WASH related } \\
\text { situation }\end{array}$ & Yes (\%) & No (\%) & & \\
\hline $\begin{array}{l}\text { Good } \\
\text { Poor }\end{array}$ & $\begin{array}{l}8(6.6) \\
10(17.5)\end{array}$ & $\begin{array}{l}113 \\
(93.4) \\
47 \\
(82.5)\end{array}$ & $\begin{array}{l}1 \\
3.0 \\
(1.1- \\
8.0)\end{array}$ & 0.03 \\
\hline
\end{tabular}

\section{DISCUSSION}

The study has assessed the status of WASH in the study area using multiple indicators. These indicators included both structural and behavioral aspects as dealt below.

The current study shows that $92 \%$ households have toilets and $6 \%$ use open field for defecation. This situation does not match with the indicators for declaration of ODF which stipulates all households in the study area must have toilets and no one should practice open field defecation. ${ }^{8}$ There could be two possible reasons for this: the first reason could be such that ODF was declared in the study area without meeting the standard criteria; the second reason could be due to deterioration of the condition after declaration of ODF. However, decreasing trend of diarrhoeal disease over the last two years after declaration of ODF has been recorded. It shows that the trend of WASH situation in the study area has improved but the target for decreasing diarrheal disease has not been mentioned. Hence, it is likely that ODF could have been declared without proper assessment of the situation prior to declaration. Similar results are found in a study conducted in some of the VDCs of Nepal. ${ }^{9}$ The study findings will have policy implication regarding declaration of ODF, as in some worst situation decision of declaration of ODF was reversed. ${ }^{9}$

WASH related practices are far lower than the ODF criteria. One such criterion set in ODF guideline is use of soap for hand washing. ${ }^{8}$ In current research, soap was found only in $60 \%$ of households. Even assuming that members of these households use soap during hand washing, a large portion of households in the study area still washes hands without using soap. Construction of toilets and their uses are not enough without proper hand washing practice for meeting the objectives of WASH. Therefore, it is imperative to seek for underlying causes of not using soap despite a high level of knowledge of mothers about hand washing.

Practices of waste management, which are additional criteria for $\mathrm{ODF}^{8}$ are even poor indicating that these aspects of environmental cleanliness may have received low priority in implementation since they do not fall in core or standard criteria of ODF. However, waste management is crucial component of WASH programme for achieving its overall goal.

Results of the study that WASH status was significantly associated with knowledge and not with economic condition explains that WASH can be improved even in low economic condition, if effective interventions are done to improve knowledge about WASH. This finding 
may have important strategic implication in improving WASH situation in the community.

Although contribution of other factors to decrease diarrhoeal disease in the study area, found in the study, cannot be excluded, it can be logically argued that such reduction is primarily attributable to the improvement of WASH in the study area after ODF declaration since diarrhoeal diseases are primarily water-borne. Such attribute of improvement of WASH to reduce diarrheal diseases has been well established by WHO through observation in many countries. ${ }^{10,11}$

This study has revealed some important results, which have academic, policy and programmatic implications. One time declaration of ODF is encouraging for the community, however not sufficient for achieving its goal to improve health. Follow up and monitoring its status to sustain it and planning for further improvement are vital, as only positive change in knowledge, behavior along with structural improvement of WASH can contribute to promote health of people through WASH interventions.

\section{CONCLUSIONS}

WASH status in the study area is lower than the criteria for ODF declaration. However, diarrhoeal disease trend of under five children is found decreasing over the last two years after the declaration of ODF. The WASH related knowledge among mothers is significantly associated with WASH status of households irrespective of their economic status.

\section{ACKNOWLEDGEMENTS}

We acknowledge Department of Community Medicine and Public Health of Maharajgunj Medical Campus, Institute of Medicine for facilitating the study and appreciate community officials and research participants for their support and kind cooperation.

\section{REFERENCES}

1. Ministry of Health Nepal, New ERA, ICF. Nepal Demographic and Health Survey 2016: Key Indicators. Kathmandu, Nepal: Ministry of Health Nepal, 2017. [Full Text]

2. DoHS. Annual Report Kathmandu: Government of Nepal, Department of Health Services, 2072/73 (2015/2016). [Full Text]

3. Sharma S, Snuggs J. Nepal CASE Study on ODF; Challenges, lessons learned and comparisons with
CLTS. How can ODF be adapted for emergencies? Care International, 2013. [Full Text]

4. Open Defecation Free (ODF) Status Updates in Nepal. National WASH Coordination Committee Secretariat, Environmental Sanitation Section, Department of Water Supply and Sewerage; 2015 [cited 2017 September 07, 2017];[Link]

5. Open Defecation Free (ODF) Status Updates in Nepal. National WASH Coordination Committee Secretariat, Environmental Sanitation Section, Department of Water Supply and Sewerage; 2015 [September 07 2017];[Full Text]

6. CBS. National Population and Housing Census 2011 (Village Development Committee/Municipality). Kathmandu, Nepal: Government of Nepal, National Planning Commission Secretariat, Central Bureau of Statistics Nepal, 2012. [Full Text]

7. Daniel WW, Cross CL. Biostatistics A foundation for Analysis in the Health Sciences, 10th edition2013. [Full Text]

8. GoN. Sanitation and Hygiene Master Plan Nepal. Kathmandu, Nepal: STEERING COMMITTEE FOR NATIONAL SANITATION ACTION 2011, Government of Nepal, 2011. [Full Text]

9. Dahal KR, Adhikari B, Tamang J. Sanitation Coverage And Impact Of Open Defecation Free (ODF) Zone With Special Reference To Nepal: A Review. International Journal of Engineering Research and Applications. 2014. [Full Text]

10. WHO. PREVENTING DIARRHOEA THROUGH BETTER WATER, SANITATION AND HYGIENE, Exposures and impacts in low- and middle-income countries. Geneva Switzerland: World Health Organization, 2014. [Full Text]

11. Unicef, WHO. 25 Progress on Sanitation and Drinking Water 2015 Update and MDG Assessment. Geneva, Switzerland: 2015. [Full Text] 